ENTREPRENEURSHIP AND SUSTAINABILITY ISSUES

ISSN 2345-0282 (online) http://jssidoi.org/jesi/

2020 Volume 7 Number 4 (June)

http://doi.org/10.9770/jesi.2020.7.4(51)

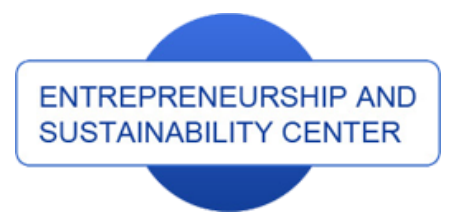

Publisher

http://jssidoi.org/esc/home

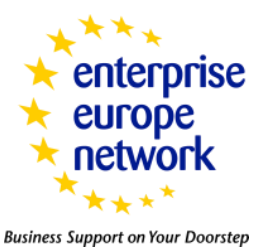

Business Support on Your Doorstep

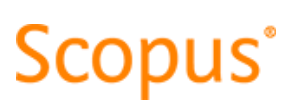

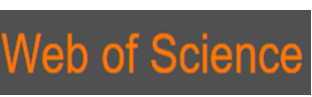

Clarivate

Analytics

\title{
ASSESSMENT THE ROLE OF RENEWABLE ENERGY IN SOCIO-ECONOMIC DEVELOPMENT OF RURAL AND ARCTIC REGIONS *
}

\section{Sergey Tishkov ${ }^{1 *}$, Anton Shcherbak ${ }^{2}$, Valentina Karginova-Gubinova ${ }^{3}$, Alexander Volkov ${ }^{4}$, Arsen Tleppayev ${ }^{5}$, Antonina Pakhomova ${ }^{6}$}

1,2,3,4 Institute of Economics, Karelian Research Centre, Russian Academy of Science, A. Nevsky Avenue, 50, Petrozavodsk, Russia

${ }^{5}$ Faculty of Economic Sciences, Kazakh-German University, Pushkin street, 111, Almaty, Kazakhstan

${ }^{6}$ Platov South-Russian State Polytechnic University (NPI), Prosveschenia street, 132, Novocherkassk, Russia

E-mails: $:^{*}$ insteco_85@mail.ru (Corresponding author)

Received 29 January 2020; accepted 25 April 2020; published 30 June 2020

\begin{abstract}
The paper overviews Russian and foreign studies on renewable energy. In view of some economic and environmental premises, namely depletion of the traditional energy sources and growing costs of their exploitation, a new alley is being paved in scientific literature and global practices for displacing traditional energy resources and providing for a substantial contribution of renewable sources to total energy consumption. In this context, the aim of this study is to determine what role renewable energy will play in the socio-economic security of territories, to identify the potential and possible applications of renewable energy. The main tasks for the study were to: identify the socio-economic implications of the transition from traditional to renewable energy sources, study the foreign experience of implementing renewable energy policies, estimate the potential and evaluate the prospects for renewable energy with the focus on rural northern regions. The potential for renewable energy market growth in Russia was estimated, specifically for the Northwestern macroregion. To provide for socio-economic security, the energy policy being developed must have an environmental and economic orientation. Primary focus in the development of renewable energy sources should be on peripheral regions, which have no electrical grids of their own and are energy deficient.
\end{abstract}

Keywords: renewable energy; energy consumption; energy sources; socio-economic security; peripheral regions

Reference to this paper should be made as follows: Tishkov, S., Shcherbak, A., Karginova-Gubinova, V., Volkov, A., Tleppayev, A., Pakhomova, A. 2020. Assessment the role of renewable energy in socio-economic development of rural and Arctic regions. Entrepreneurship and Sustainability Issues, 7(4), 3354-3368. http://doi.org/10.9770/jesi.2020.7.4(51)

\footnotetext{
* Supported by the RFBR, Russia, Project No. 20-310-70005
} 


\section{ENTREPRENEURSHIP AND SUSTAINABILITY ISSUES}

ISSN 2345-0282 (online) http://jssidoi.org/jesi/

2020 Volume 7 Number 4 (June)

http://doi.org/10.9770/jesi.2020.7.4(51)

JEL Classifications: A 10; Q 40; Q 42

Additional disciplines ecology and environment; energetics and thermoenergetics.

\section{Introduction}

The rising interest in renewable energy is driven by several factors. The key ones are depletion of the sources of traditional fossil fuels combined with growing costs of their extraction; heavy environmental impact caused by fossil energy production and use, and the associated demand for treatment facilities and actions. Experts have estimated that with current consumption rates, primary energy sources of coal will suffice for no more than 850 years, natural gas for 270 years, oil for 180 years. The quality of the hydrocarbons' reserves will also be constantly declining (Vylegzhanin 2015; World Energy Council 2016).

An example of a negative environmental impact of fossil fuels is $\mathrm{CO} 2$ and methane emissions, which notably deteriorate the quality of the environment. An emerging, yet underestimated application for solar energy is agriculture. Solar-powered vegetaria can deliver products 1.5-2 months earlier than unheated greenhouses, depending on the crop. The cost of a vegetarium, on the other hand, is commensurate with a regular greenhouse. Vegetaria can be used by large agricultural producers as well as by small-scale farmers, and in private subsistence farming. Thus, the construction of solar vegetaria would enhance food security in terms of some product categories in some regions of Russia. This is of particular relevance for northern regions in the Russian periphery, away from large logistic nodes.

Novelty of this research focuses on studying the northern and Arctic regions, develop new and refine existing approaches to research and development of mathematical models of energy efficiency of the Arctic zone economy; development of methodological approach to formation of mathematical models and scenarios of energy development and socio-economic development, including economic security based on interaction of macro- and meso-level. The research limitations are that not all data was available to all countries from the sample, as primary data were collected through a variety of studies, each conducted on its own sample of countries.

\section{Theoretical background}

Estimating the potential of renewable energy, researchers assume that the average required energy capacity is two $\mathrm{kW}$ per person per day. Each square meter of the earth surface can potentially yield ca. $500 \mathrm{~W}$. With the conversion efficiency of $4 \%$, it takes ten square meters per person. Given the average population density, this amount is quite achievable (Cho 2007). Earlier studies have corroborated the statement that renewable sources of energy are essential for mitigating climate change, in particular when implementing the Kyoto Protocol and 'green credits' trading. Renewable sources can be used in the electric energy sector and as environment-friendly vehicle biofuels (Jäger-Waldau 2007; Li et al. 2018), as well as in space exploration (Komerath et al 2011; Pisacane et al 2005).

It was shown that increased utilization of renewable energy will help reduce the price of non-renewable sources, namely natural gas. E.g., each megawatt hour renewable energy may potentially save end users at least UDS 7.520 (Wiser 2007). At the same time, the analysis of marginal cost curves has confirmed that in some countries, such as Spain, renewable energy generation is now inefficient, wherefore its prices cannot be competitive in the electricity market (Paz Espinosa et al. 2018; Hernández et al. 2011). The general demand for a more efficient use of resources was postulated by German economists E. von Weizsäcker, A.B. Lovins and L.H. Lovins. Their ideas and approaches underlie the European sustainable development strategy (Weizsäcker et al 1997). 


\section{ENTREPRENEURSHIP AND SUSTAINABILITY ISSUES}

ISSN 2345-0282 (online) http://jssidoi.org/jesi/

2020 Volume 7 Number 4 (June)

http://doi.org/10.9770/jesi.2020.7.4(51)

In some countries, the transition to renewable energy is impeded by influential business groups. In Japan, for instance, in spite of energy shortages, the introduction of renewable energy sees some resistance from the haves. While photovoltaic generation better meets their interests than windmills, solar parks are procedurally easier to deploy. Yet, the country's government policy undertakes to stick to the energy efficiency principle (Moe 2012). There are, however, some economic challenges involved in the transition to renewable energy. Thus, the analysis of data for 24 European countries covering the period from 1990 to 2007 showed that coal hinders economic growth, natural gas has no effect, but the use of oil promotes growth. Hence, abandonment of some natural resources may cause economic growth to slow down (Marques et al. 2012).

The background for research on renewable energy development in Russia is systemic studies of the energy industry at the level of countries and their individual regions (Zheng et al 2019; Pablo-Romero et al 2019; Sarma et al 2019). Energy security issues (Yoo 2003) and the environmental effect of the energy industry (Sun et al. 2019; Dhar et al. 2019; Hájek et al. 2019) have been identified. Proceeding from this identified role, the prospects for renewable energy utilization were evaluated (Proskuryakova et al. 2019; Olkkonen et al. 2016) and recommendations were given on its implementation, regarding both strategic planning and guarantee of some rate of return for investors: by improving the legislative framework, introducing grid connection cost recovery schemes and fixed feed-in tariffs (Sadorsky 2012; Wang 2019; Lanshina 2018). The transition to renewable energy is particularly promising in decentralized power supply systems, where most of the generation today is by diesel power plants with their high operating costs (Velkin 2015).

\section{Material and Method}

The studies on renewable energy development and the projects implemented so far suggest there is extensive potential for the use of all major types of renewable energy in Russia. The key challenge in drawing up a common methodology for the study of this process is the diversity of applicable formats and methods.

The assessment of the role of renewable sources of energy in the socio-economic development of regions included:

- comparison of traditional and alternative sources, their comparative strengths and weaknesses;

- $\quad$ identification of the qualitative and quantitative effects of completed projects in the renewable energy market;

- $\quad$ estimation of the actual and potential scope of use of renewable energy sources, including for specific most promising types, considering the resources available.

The development potential of renewable energy was estimated both as potential generation capacity and as the share in total consumption.

The results obtained in the study have enabled conclusions to be drawn concerning the current and prospective effects of renewable energy on the socio-economic security of territories.

Renewable energy sources reduce environmental charges and increase economic growth. The hypothesis is an increase in the share of renewable energy leads to a reduction in $\mathrm{CO} 2$ emissions. The one model was built according to the data of the European Union countries from 1990 to 2018 and other - for Belarus, Russia and Kazakhstan (World Bank Statistics, Eurostat and Enerdata, see Table 1, Figure 1, Table 2, Figure 2). We take to the data of the European Union countries, because the share of renewable is a rapidly increase in last years. 
ENTREPRENEURSHIP AND SUSTAINABILITY ISSUES

ISSN 2345-0282 (online) http://jssidoi.org/jesi/

2020 Volume 7 Number 4 (June)

http://doi.org/10.9770/jesi.2020.7.4(51)

Table 1. Renewable electricity output in Belarus, Kazakhstan, Russia (\% of total electricity output)

\begin{tabular}{|c|c|c|c|}
\hline Country Name & Belarus & Kazakhstan & Russian Federation \\
\hline 1991 & 0,046469601 & 8,373650912 & 15,69414031 \\
\hline 1993 & 0,056939075 & 9,850989102 & 18,14990447 \\
\hline 1994 & 0,060515336 & 13,82441978 & 20,00717812 \\
\hline 1995 & 0,080263264 & 12,49756229 & 20,42662271 \\
\hline 1998 & 0,119189511 & 12,49567606 & 19,19112939 \\
\hline 1999 & 0,07165485 & 12,91001726 & 18,99243743 \\
\hline 2000 & 0,103444312 & 14,67344712 & 18,72960564 \\
\hline 2001 & 0,11969836 & 14,21284978 & 19,56702383 \\
\hline 2002 & 0,109615966 & 15,23773611 & 18,26085783 \\
\hline 2007 & 0,157089447 & 10,66738035 & 17,52064093 \\
\hline 2008 & 0,20828578 & 9,287039227 & 15,91410503 \\
\hline 2009 & 0,345667632 & 8,739677296 & 17,64404648 \\
\hline 2010 & 0,37254621 & 9,706458873 & 16,12058881 \\
\hline 2011 & 0,428571429 & 9,10424318 & 15,80302393 \\
\hline 2012 & 0,555212832 & 8,4 & 15,56373111 \\
\hline 2013 & 0,844256832 & 8,1 & 17,17463022 \\
\hline 2014 & 0,722614078 & 8,7 & 16,5682512 \\
\hline 2015 & 0,815679831 & 10,3 & 15,85579515 \\
\hline 2016 & 0,815679831 & 12,7 & 17 \\
\hline 2017 & 2,2 & 11,3 & 17,2 \\
\hline
\end{tabular}


ENTREPRENEURSHIP AND SUSTAINABILITY ISSUES

ISSN 2345-0282 (online) http://jssidoi.org/jesi/

2020 Volume 7 Number 4 (June)

http://doi.org/10.9770/jesi.2020.7.4(51)

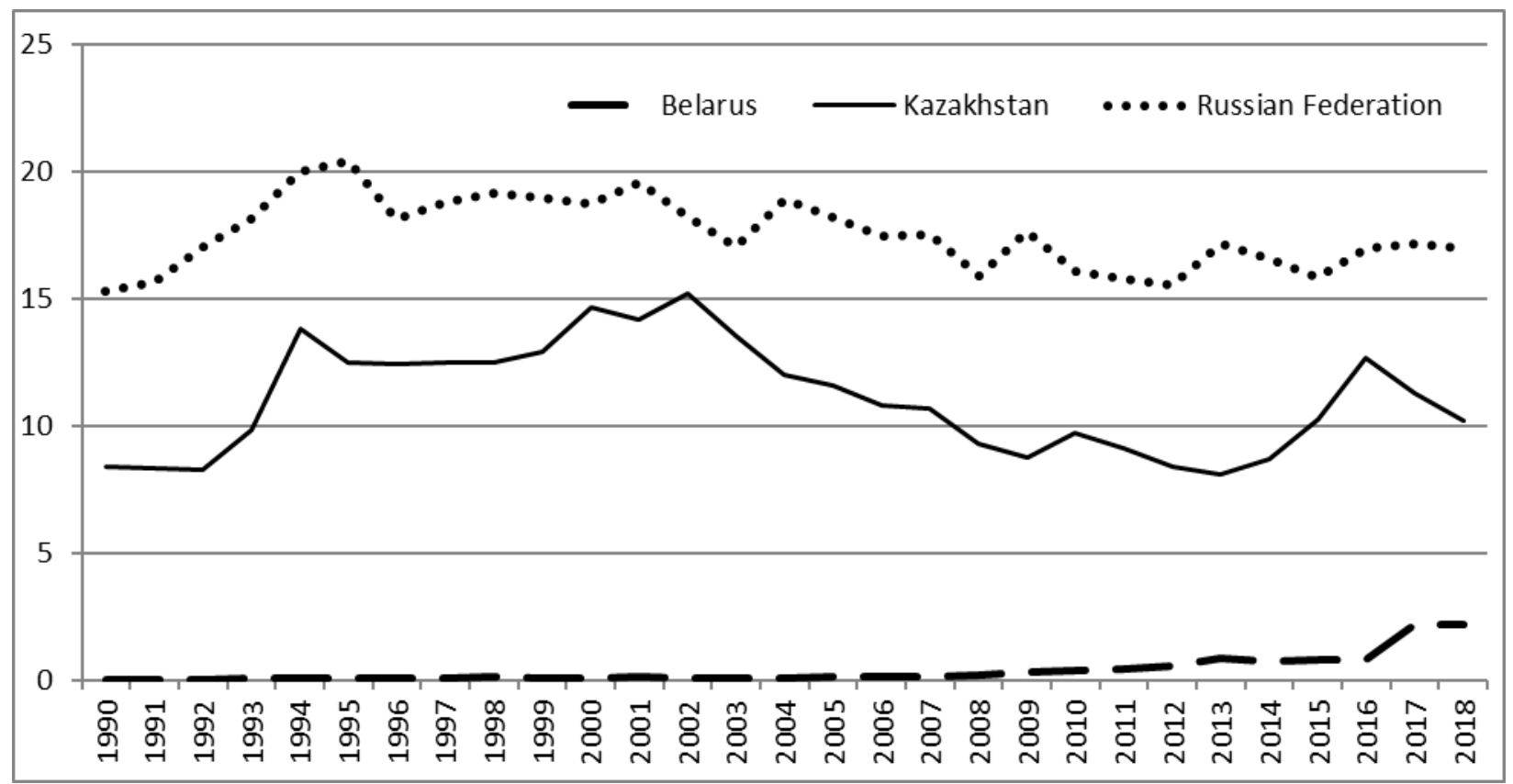

Figure 1. Renewable electricity output in Belarus, Kazakhstan, Russia (\% of total electricity output)

Source: World Bank Statistics and National Agencies of Statistics

Table 2. Renewable electricity output in some European countries (\% of total electricity output)

\begin{tabular}{|c|c|c|c|c|c|c|c|c|}
\hline Country & Belgium & $\begin{array}{c}\text { Czech } \\
\text { Republic }\end{array}$ & Germany & Denmark & Spain & France & $\begin{array}{c}\text { United } \\
\text { Kingdom }\end{array}$ & Italy \\
\hline 1990 & 0,789564 & 1,864431 & 3,486351 & 3,175275 & 17,21625 & 13,369879 & 1,828767 & 16,37602 \\
\hline 1991 & 0,752957 & 1,80603 & 3,168753 & 2,892325 & 17,97039 & 13,220198 & 1,656439 & 20,84651 \\
\hline 1992 & 0,864025 & 2,373978 & 3,697964 & 4,398464 & 12,50925 & 15,453978 & 2,005662 & 20,55392 \\
\hline 1993 & 0,723583 & 2,608518 & 3,92737 & 4,730088 & 16,16325 & 14,238354 & 1,777626 & 20,57976 \\
\hline 1994 & 0,841031 & 3,050232 & 4,461686 & 4,295431 & 18,06068 & 17,058195 & 2,139842 & 21,08945 \\
\hline 1995 & 0,908646 & 3,973586 & 4,866989 & 5,035639 & 14,72016 & 15,361125 & 2,066535 & 17,466 \\
\hline 1996 & 0,746626 & 3,54261 & 4,821397 & 3,880034 & 23,79085 & 13,448621 & 1,62748 & 19,30801 \\
\hline 1997 & 0,755192 & 3,414984 & 4,20831 & 6,6095 & 19,54617 & 13,264534 & 1,989232 & 18,743 \\
\hline 1998 & 0,924764 & 3,068519 & 4,508169 & 9,546859 & 19,07369 & 12,767857 & 2,395321 & 18,32252 \\
\hline 1999 & 1,0196 & 3,675244 & 5,197224 & 11,25128 & 13,26681 & 14,46674 & 2,632717 & 19,79325 \\
\hline 2000 & 1,261281 & 3,132586 & 6,198531 & 15,45502 & 15,61373 & 12,967876 & 2,663105 & 18,84819 \\
\hline 2001 & 1,367371 & 3,471455 & 6,512444 & 15,49471 & 21,15357 & 14,256372 & 2,497332 & 19,98867 \\
\hline 2002 & 1,405997 & 3,944996 & 7,6427 & 17,28053 & 13,83062 & 11,597276 & 2,893173 & 17,4088 \\
\hline 2003 & 1,426503 & 2,268885 & 7,552978 & 17,49015 & 21,67904 & 11,230018 & 2,684947 & 16,3708 \\
\hline 2004 & 1,774685 & 3,271273 & 9,267474 & 23,55574 & 18,1347 & 11,242989 & 3,613032 & 18,21338 \\
\hline 2005 & 2,457152 & 3,822729 & 10,15021 & 27,07057 & 14,60139 & 9,8606467 & 4,283482 & 16,31822 \\
\hline 2006 & 3,499787 & 4,207808 & 11,32201 & 20,17277 & 17,64282 & 10,947576 & 4,602089 & 16,45644 \\
\hline 2007 & 3,982726 & 3,88542 & 13,93801 & 26,2107 & 19,3093 & 11,690926 & 5,010293 & 15,48072 \\
\hline 2008 & 5,285764 & 4,47926 & 14,69923 & 27,57265 & 19,98309 & 12,979209 & 5,677052 & 18,55119 \\
\hline 2009 & 6,056388 & 5,701196 & 16,07855 & 27,65852 & 25,38125 & 13,127164 & 6,766808 & 24,01894 \\
\hline 2010 & 6,920806 & 6,918136 & 16,72707 & 31,9824 & 32,77554 & 13,857359 & 6,812813 & 25,76036 \\
\hline 2011 & 9,410879 & 8,35254 & 20,38328 & 40,25377 & 30,02164 & 11,574747 & 9,489053 & 27,59473 \\
\hline 2012 & 12,81288 & 9,303586 & 23,00046 & 48,32742 & 29,58475 & 14,827354 & 11,42396 & 31,02039 \\
\hline 2013 & 14,20939 & 10,82341 & 24,07255 & 45,96034 & 39,58358 & 17,045286 & 14,98848 & 38,90535 \\
\hline
\end{tabular}


ENTREPRENEURSHIP AND SUSTAINABILITY ISSUES

ISSN 2345-0282 (online) http://jssidoi.org/jesi/

2020 Volume 7 Number 4 (June)

http://doi.org/10.9770/jesi.2020.7.4(51)

\begin{tabular}{|l|c|c|c|c|c|c|c|c|}
\hline 2014 & 17,08064 & 10,77841 & 26,1301 & 55,90045 & 40,10526 & 16,455905 & 19,26285 & 43,39161 \\
\hline 2015 & 20,80002 & 11,40457 & 29,23177 & 65,50592 & 34,94989 & 15,857667 & 24,84005 & 38,67923 \\
\hline 2016 & 17,9 & 12,7 & 29,9 & 60,44681 & 39,3 & 18,4 & 25,4 & 37,9 \\
\hline 2017 & 18,8 & 12,4 & 34,2 & 70,6113 & 32,8 & 17,2 & 30,1 & 35,7 \\
\hline 2018 & 23,3 & 11,9 & 36 & 68,85025 & 38,6 & 19,9 & 34 & 39,9 \\
\hline
\end{tabular}

Table 2. (continuation) Renewable electricity output in some European countries (\% of total electricity output)

\begin{tabular}{|c|c|c|c|c|c|c|}
\hline Country & Netherlands & Norway & Poland & Portugal & Romania & Sweden \\
\hline 1990 & 1,119942 & 99,79196 & 1,095116 & 34,71526 & 17,74402 & 51,00011 \\
\hline 1991 & 1,256991 & 99,80102 & 1,136158 & 33,12365 & 25,68174 & 44,30088 \\
\hline 1992 & 1,287909 & 99,81727 & 1,238073 & 18,57003 & 21,5924 & 52,33321 \\
\hline 1993 & 1,4347 & 99,80371 & 1,175453 & 30,45499 & 23,01716 & 52,92433 \\
\hline 1994 & 1,575119 & 99,64299 & 1,338395 & 37,14495 & 23,66149 & 43,02873 \\
\hline 1995 & 1,730999 & 99,66215 & 1,42657 & 28,30075 & 28,16623 & 47,57878 \\
\hline 1996 & 2,125891 & 99,49951 & 1,461818 & 45,86106 & 25,68052 & 38,40159 \\
\hline 1997 & 2,331172 & 99,57735 & 1,512754 & 41,67936 & 30,65724 & 48,27755 \\
\hline 1998 & 2,555013 & 99,61608 & 1,799376 & 36,36107 & 35,31105 & 49,18289 \\
\hline 1999 & 2,890913 & 99,56087 & 1,679988 & 20,09135 & 36,06784 & 48,27433 \\
\hline 2000 & 3,315817 & 99,71511 & 1,628787 & 29,66891 & 28,45535 & 57,24673 \\
\hline 2001 & 3,525405 & 99,5203 & 1,936391 & 34,09504 & 27,70393 & 51,56162 \\
\hline 2002 & 4,140403 & 99,58308 & 1,941768 & 21,32092 & 29,32128 & 48,49693 \\
\hline 2003 & 4,092214 & 99,39908 & 1,49991 & 38,05378 & 24,05151 & 43,38265 \\
\hline 2004 & 5,243346 & 99,35063 & 2,102262 & 27,47005 & 29,23415 & 44,94933 \\
\hline 2005 & 7,450886 & 99,47175 & 2,4762 & 17,88343 & 34,02117 & 51,29416 \\
\hline 2006 & 8,146065 & 99,31613 & 2,66913 & 32,36578 & 29,2837 & 49,6008 \\
\hline 2007 & 7,210574 & 99,13454 & 3,420235 & 34,58291 & 25,94977 & 52,0269 \\
\hline 2008 & 8,86176 & 99,40296 & 4,271217 & 32,19791 & 26,51641 & 54,30905 \\
\hline 2009 & 9,531097 & 96,57044 & 5,742418 & 36,96496 & 26,9358 & 58,41996 \\
\hline 2010 & 9,387943 & 95,73265 & 6,931103 & 52,80773 & 33,48785 & 55,30176 \\
\hline 2011 & 10,81228 & 96,49442 & 8,053679 & 46,4751 & 26,31494 & 55,9446 \\
\hline 2012 & 12,11446 & 97,95491 & 10,43776 & 42,50044 & 25,39558 & 59,06775 \\
\hline 2013 & 11,97511 & 97,70227 & 10,40531 & 58,31915 & 34,42155 & 54,0335 \\
\hline 2014 & 11,32105 & 97,65553 & 12,51861 & 60,7402 & 41,60609 & 55,83769 \\
\hline 2015 & 12,44208 & 97,70987 & 13,8024 & 47,52637 & 39,74697 & 63,26275 \\
\hline 2016 & 12,8 & 97,8 & 14 & 55,5 & 42,2 & 57,2 \\
\hline 2017 & 15 & 97,8 & 14,5 & 41 & 38,3 & 57,5 \\
\hline 2018 & 15,7 & 97,9 & 13 & 52,2 & 41,3 & 55,3 \\
\hline
\end{tabular}

Source: World Bank Statistics and Eurostat 


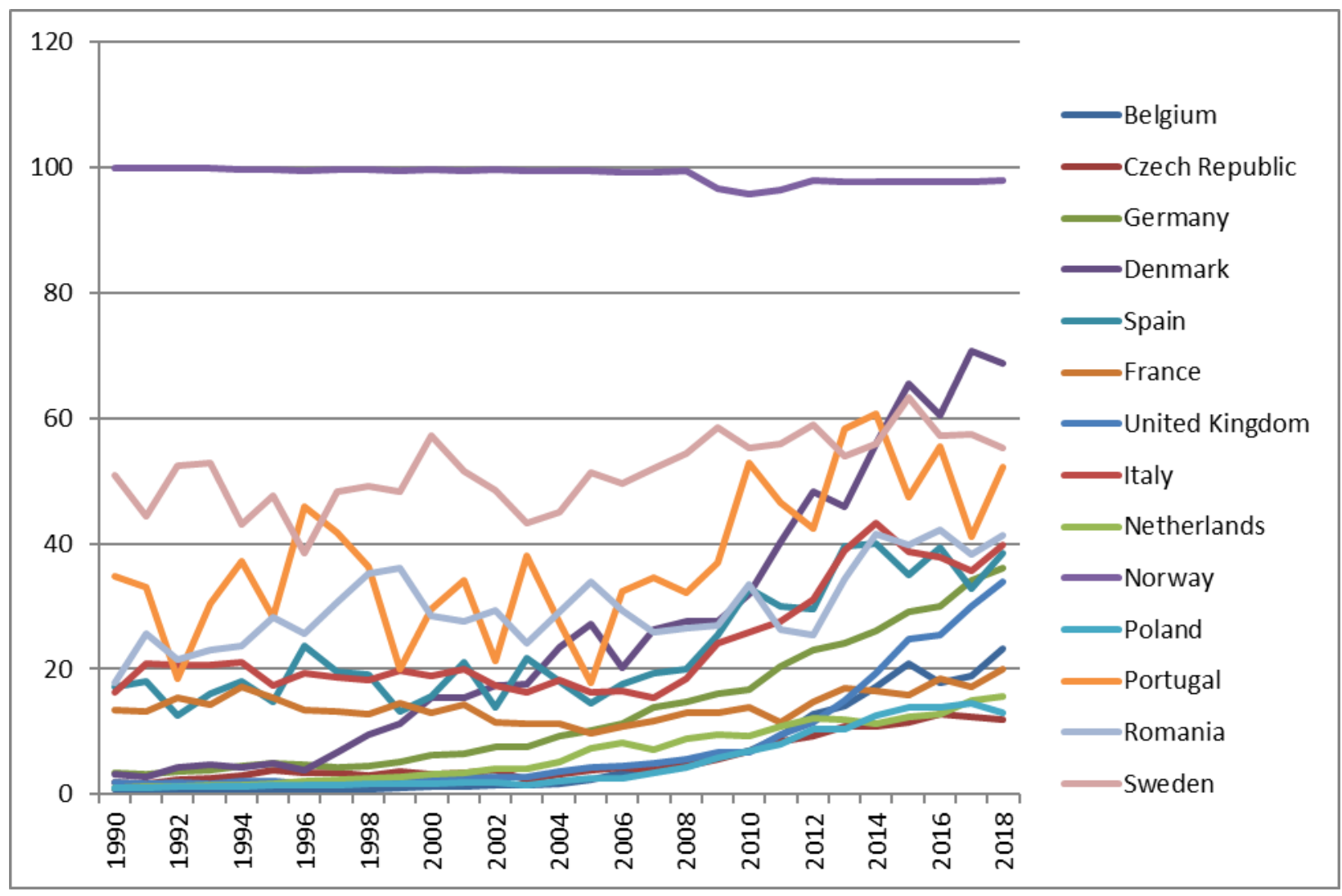

Figure 2. Renewable electricity output in some European countries (\% of total electricity output)

Source: World Bank Statistics and Eurostat

To investigate the relationship between $\mathrm{CO} 2$ emissions per capita, fossil fuel energy consumption, renewable electricity and GDP per capita, we apply model proposed Ito (2017) and the long-run model is given by the following equation:

$\mathrm{CO} 2 \mathrm{emmisions}=\mathrm{f}($ FuelCons, Renewable electricity, GDP $)$

Making the log linear form of the both sides of the Equation (1), we obtain the following Equation (2):

$\operatorname{lnCO} 2_{\text {it }}=\beta_{0}+\beta_{1} \operatorname{lnFuelCons}_{\text {it }}+\beta_{2} \operatorname{lnRW}_{\mathrm{it}}+\beta_{3} \operatorname{lnGDP}_{\mathrm{it}}+\varepsilon_{\mathrm{it}}$,

where:

ln denotes the natural logarithm;

$\beta_{1}, \beta_{2}$ and $\beta_{3}$ parameters are the long-run elasticities of $\mathrm{CO} 2$ emissions per capita to Fossil fuel energy consumption (\% of total), share of Renewable electricity (\% of total electricity output) and GDP per capita;

$\operatorname{lnCO} 2$ it is a logarithmic meter corresponding to $\mathrm{CO} 2$ emissions (metric tons per capita);

lnFuelCons sit is a logarithmic meter corresponding to the Fossil fuel energy consumption (\% of total);

lnRWit is a logarithmic meter corresponding to the share of Renewable electricity (\% of total electricity output); lnGDPit is a logarithmic meter corresponding to the GDP per capita. 


\section{Results and Discussion}

According the econometric analysis, the panel unit root tests are provided for all of the parameters of equation (2). Keeping in mind the basic idea behind cointegration, it is necessary to determine the order of integration of each variable before proceeding to using cointegration techniques. The results of the panel unit root tests for all of variables of equation (2), using the Levin, Lin \& Chu test, ADF Fisher, and PP Fisher tests, are presented in Table 3.

Table 3. Panel unit root results

\begin{tabular}{|c|c|c|c|c|c|c|}
\hline \multirow[t]{2}{*}{ Variables } & \multirow{2}{*}{\multicolumn{2}{|c|}{ Test Statistics }} & \multicolumn{2}{|c|}{ Panel data 1 - EU countries } & \multicolumn{2}{|c|}{$\begin{array}{c}\text { Panel data } 2 \text { - Belarus, Russia } \\
\text { and Kazakhstan }\end{array}$} \\
\hline & & & Level & $\begin{array}{c}\text { First } \\
\text { Difference }\end{array}$ & Level & $\begin{array}{c}\text { First } \\
\text { Difference }\end{array}$ \\
\hline \multirow{6}{*}{$\operatorname{lnCO} 2$} & \multirow{2}{*}{ Levin, Lin \& Chu t } & Statistic & 2.438 & -7.278 & -0.835 & -3.835 \\
\hline & & Prob. & 0.993 & 0.000 & 0.202 & 0.000 \\
\hline & \multirow[t]{2}{*}{ ADF - Fisher Chi-square } & Statistic & 17.734 & 134.559 & 4.368 & 21.564 \\
\hline & & Prob. & 0.933 & 0.000 & 0.627 & 0.002 \\
\hline & \multirow{2}{*}{ PP - Fisher Chi-square } & Statistic & 22.661 & 296.535 & 6.620 & 33.777 \\
\hline & & Prob. & 0.750 & 0.000 & 0.357 & 0.000 \\
\hline \multirow{6}{*}{ lnFuelCons } & \multirow[t]{2}{*}{ Levin, Lin \& Chu t } & Statistic & 2.052 & -7.387 & -0.762 & -2.260 \\
\hline & & Prob. & 0.980 & 0.000 & 0.223 & 0.012 \\
\hline & \multirow[t]{2}{*}{ ADF - Fisher Chi-square } & Statistic & 8.622 & 145.579 & 4.708 & 34.130 \\
\hline & & Prob. & 0.999 & 0.000 & 0.582 & 0.000 \\
\hline & \multirow[t]{2}{*}{ PP - Fisher Chi-square } & Statistic & 10.204 & 286.086 & 7.586 & 69.541 \\
\hline & & Prob. & 0.999 & 0.000 & 0.270 & 0.000 \\
\hline \multirow{6}{*}{$\operatorname{lnRW}$} & \multirow[t]{2}{*}{ Levin, Lin \& Chu t } & Statistic & 1.378 & -7.846 & 2.348 & -2.640 \\
\hline & & Prob. & 0.916 & 0.000 & 0.991 & 0.004 \\
\hline & \multirow{2}{*}{ ADF - Fisher Chi-square } & Statistic & 11.090 & 81.445 & 4.666 & 25.880 \\
\hline & & Prob. & 0.998 & 0.000 & 0.587 & 0.000 \\
\hline & \multirow[t]{2}{*}{ PP - Fisher Chi-square } & Statistic & 21.756 & 153.196 & 5.820 & 52.998 \\
\hline & & Prob. & 0.793 & 0.000 & 0.444 & 0.000 \\
\hline \multirow{6}{*}{$\operatorname{lnGDP}$} & \multirow[t]{2}{*}{ Levin, Lin \& Chu t } & Statistic & -2.269 & -9.856 & 0.108 & -2.942 \\
\hline & & Prob. & 0.012 & 0.000 & 0.543 & 0.001 \\
\hline & \multirow[t]{2}{*}{ ADF - Fisher Chi-square } & Statistic & 13.679 & 142.515 & 1.260 & 15.055 \\
\hline & & Prob. & 0.989 & 0.000 & 0.974 & 0.019 \\
\hline & \multirow[t]{2}{*}{ PP - Fisher Chi-square } & Statistic & 12.569 & 162.261 & 0.878 & 23.757 \\
\hline & & Prob. & 0.995 & 0.000 & 0.990 & 0.000 \\
\hline
\end{tabular}

Source: Computed by this study

The results in Table 3 point out that the hypothesis that the levels of all variables under study contain a unit root is accepted at the $1 \%$ significance level. The test results indicate that the first difference variables are stationary. Thus, the results allowed the test for panel cointegration between the GDP, RW, CO2, FuelCons. In Table 4, the results of using the Pedroni panel cointegration tests are presented. 
Table 4. Pedroni panel cointegration tests

\begin{tabular}{|c|c|c|c|c|c|}
\hline \multirow{4}{*}{ Variables } & Test Statistics & \multicolumn{2}{c|}{ Panel data 1 - EU countries } & \multicolumn{2}{c|}{ Panel data 2- Belarus, Russia and } \\
Kazakhstan
\end{tabular}

Source: Computed by this study

The cointegration reveals that there is a long-run relationship between the variables for EU countries (which is indicated by the panel PP, panel ADF, group ADF and group PP statistics in Table 4) and unclear results for panel - Belarus, Russia and Kazakhstan. According table 4, panel 2 have a cointegration relationship by only ADF-Statistic.

In Table 5, the findings of the use of the FMOLS and DOLS panel cointegration techniques are presented.

Table 5. Results of model

\begin{tabular}{|c|c|c|c|c|c|c|c|c|c|c|c|}
\hline & \multirow[t]{2}{*}{ Methods } & \multicolumn{3}{|c|}{ lnFuelCons } & \multicolumn{3}{|c|}{$\operatorname{lnRW}$} & \multicolumn{3}{|c|}{$\operatorname{lnGDP}$} & \multirow[t]{2}{*}{ R-squared } \\
\hline & & $\begin{array}{c}\text { Coeffici } \\
\text { ent }\end{array}$ & $\begin{array}{c}\mathrm{t}- \\
\text { Statistic }\end{array}$ & Prob. & $\begin{array}{c}\text { Coeffici } \\
\text { ent }\end{array}$ & $\begin{array}{c}\mathrm{t}- \\
\text { Statistic }\end{array}$ & Prob. & $\begin{array}{l}\text { Coeffi } \\
\text { cient }\end{array}$ & $\begin{array}{c}\mathrm{t}- \\
\text { Statistic }\end{array}$ & Prob. & \\
\hline \multirow[t]{2}{*}{$\begin{array}{l}\text { Panel data } \\
1 \text { - EU } \\
\text { countries }\end{array}$} & $\begin{array}{l}\text { Panel Fully } \\
\text { Modified } \\
\text { Least } \\
\text { Squares } \\
\text { (FMOLS) }\end{array}$ & 1.483 & 13.792 & 0.00 & -0.0612 & -5.672 & 0.00 & 0.0275 & 1.662 & 0.097 & 0.96 \\
\hline & $\begin{array}{c}\text { Panel } \\
\text { Dynamic } \\
\text { Least } \\
\text { Squares } \\
\text { (DOLS) }\end{array}$ & 1.309 & 10.870 & 0.00 & -0.046 & -4.05 & 0.00 & -0.004 & -0.246 & 0.806 & 0.98 \\
\hline \multirow[t]{2}{*}{$\begin{array}{c}\text { Panel data } \\
2- \\
\text { Belarus, } \\
\text { Russia and } \\
\text { Kazakhstan }\end{array}$} & $\begin{array}{l}\text { Panel Fully } \\
\text { Modified } \\
\text { Least } \\
\text { Squares } \\
\text { (FMOLS) }\end{array}$ & 5.856 & 2.859 & 0.005 & -0.050 & -1.307 & 0.195 & 0.124 & 5.520 & 0.000 & 0.85 \\
\hline & $\begin{array}{c}\text { Panel } \\
\text { Dynamic } \\
\text { Least } \\
\text { Squares } \\
\text { (DOLS) }\end{array}$ & 7.190 & 3.212 & 0.002 & -0.061 & -1.237 & 0.221 & 0.136 & 5.050 & 0.027 & 0.94 \\
\hline
\end{tabular}

Source: Computed by this study 


\section{ENTREPRENEURSHIP AND SUSTAINABILITY ISSUES}

ISSN 2345-0282 (online) http://jssidoi.org/jesi/

2020 Volume 7 Number 4 (June)

http://doi.org/10.9770/jesi.2020.7.4(51)

According results, for European countries the fossil fuel energy consumption contribute the the $\mathrm{CO} 2$ emissions and renewable electricity contributes to reductions in emissions. For Belarus, Russia and Kazakhstan fossil fuel and per capita GDP lead to an increase in the emissions. For European countries, coefficient of FuelCons suggests that a $1 \%$ increase in fossil fuel energy consumption will lead to an increase in the $\mathrm{CO} 2$ emissions per capita of $1.5 \%$ and the coefficient of RW suggests that a $1 \%$ increase in share of renewable energy will lead to a decrease in the $\mathrm{CO} 2$ emissions per capita of $0.06 \%$ for FMOLS estimation (DOLS estimation shows 1.3 and -0.05 respectively), the GDP per capita don't influence on emissions (coefficient is statistically insignificant). According results, for Belarus, Russia and Kazakhstan the coefficient of GDP suggests that a $1 \%$ increase in per capita GDP will lead to an increase in the $\mathrm{CO} 2$ emissions per capita of $0.12 \%$ and the coefficient of FuelCons suggests that a $1 \%$ increase in fossil fuel energy consumption will lead to a increase in the $\mathrm{CO} 2$ emissions per capita of $6 \%$ for FMOLS estimation (DOLS estimation shows 0.14 and 7 respectively), the renewable electricity don't influence on emissions (coefficient is statistically insignificant).

Thus according to the panel data model, the increase in the share of renewable energy in the long run reduces the $\mathrm{CO} 2$ emission by the example of European countries. For countries of panel 2, renewable electricity don't influence on emissions due to low share of renewable energy in total electricity output compared to Germany or Portugal.

Our empirical findings are as follows: (i) renewable energy consumption contributes to reductions in emissions for European countries, but we don't find relation for Belarus, Russia and Kazakhstan; (ii) fossil fuel energy consumption lead to increase the $\mathrm{CO} 2$ emissions in all countries in the long run.

Owing to modern techniques, a majority of agricultural enterprises (animal, poultry, breeding farms) can fully satisfy their heat and power demand using their own biogas. In addition, biogas can serve as an alternative fuel for farm machinery.

The biogas production technology should also be applied at large municipal wastewater treatment facilities. The raw material in this case is sewage. Biogas (methane) is a greenhouse gas which, formed under natural conditions, is harmful for the environment, imposing extra burden on the economy (Chang 2017). Since wastewater has to be treated anyway, the use of biogas can help treatment facilities reduce their energy costs and sometimes get extra revenues from selling biogas and its end products out to the market.

Biogas production also proves beneficial in municipal landfills. Methane collection can be organized there. In the process, municipal wastes will be recycled, new energy resources will be generated, greenhouse emissions will be reduced, and environmental improvements will be achieved. Such landfills are quite common in a majority of developed countries, including the USA, China, Japan, the Netherlands, Belgium, and many others. Thus, in the subarctic city of Oulu (Finland), the municipal landfill Oiva Roina has been reconstructed, so that in addition to waste processing it now extracts gas and generates power. Gas is extracted by specialized pumps connected to pipelines running through the body of the landfill. There is a $200 \mathrm{kWh}$ power station in the landfill premises with four power generators operating on methane, $50 \mathrm{kWh}$ installed capacity each. This capacity suffices to cover all energy demands of the company. Excessive gas is sold to nearby enterprises. This recycling technology has proven efficiency and could be applied in Russian municipal waste landfills, considering how pressing the waste recycling problem is today in a majority of large settlements across Russia.

The results are consistent with previous studies. In particular, data from African countries for the period 19802014 and 1980-2011 confirmed respectively the existence of a short-run (Adams et al 2019) and a long-run (Adams et al 2019; Inglesi-Lotz et al 2018) relationship between the renewable and non-renewable energy and $\mathrm{CO} 2$ emissions. The study also found a unidirectional causality running from renewable energy consumption to $\mathrm{CO} 2$ emissions (Inglesi-Lotz et al 2018). The existence of a link between the use of non-renewable energy and 


\section{ENTREPRENEURSHIP AND SUSTAINABILITY ISSUES}

ISSN 2345-0282 (online) http://jssidoi.org/jesi/

2020 Volume 7 Number 4 (June)

http://doi.org/10.9770/jesi.2020.7.4(51)

CO2 emissions was also confirmed in an earlier study of the Tunisian economy (Cherni et al 2017). At the same time, data from the MENA region (Middle East and North Africa) showed that a transition to renewable energy consumption can only slightly explain changes in $\mathrm{CO} 2$ emissions. The reason for this is the weak distribution of renewable energy in the MENA countries (Charfeddine 2019).

Renewable energy development plans should take into account the resources available in a territory. Take the case of Northwest Russian regions. Northwest Russia has good premises for the development of the renewable energy sector, and many regions implement pilot projects, get expert reviews for projects and search for instruments to implement them. An important application for renewable energy sources is the conversion of district boiler houses from coal and heavy oil to biomass, viz. wood wastes, peat, etc. With heavy oil prices in Russia growing constantly, wood residues as feedstock for heat production are gradually becoming competitive. Hence, forest resources in northern regions of Russia (especially Republic of Karelia and Arkhangelsk Region) can be utilized to produce renewable fuels, such as chips and pellets. Boiler houses in all districts of Karelia are getting reequipped to be converted to local fuels. Some boiler houses in the region are already powered by local fuels such as chips and peat. They are situated in Suojarvi, Veshkelitsa, Porosozero, Harlu, Essoila and many other towns and villages.

Finnish experience deserves special attention. A Finnish company has developed an integrated solution for the heating and hot water supply of private houses where a solar power installation is integrated in the utility system. The main element of this system is a heat accumulator combined with a solar collector. Where needed, the system can be supplemented with a diesel or gas boiler so that the heat and hot water supply of the house is provided by the integrated solar energy-diesel/gas system. In this system, the water heated in solar collectors is supplied to the heat accumulator and then distributed among consumers, with additional heating by a diesel or gas boiler if necessary. The boiler ensures that even when solar energy is in deficit, e.g. in wintertime, the consumer gets adequate heating and hot water supply.

As regards municipalities, the development of their economies is directly dependent on distance to the region's capital city, the only exception being centers of innovation. In Karelia, the latter are represented by the borderland towns of Kostomuksha and Sortavala.

Since the beginning of reforms, Karelian economy has seen a substantial decline, most importantly in industry and agriculture. Employment levels in a majority of municipalities dropped 4-6-fold, and it is only in Kostomukshsky and Sortavalsky Districts that the socio-economic situation is slightly better, owing to the presence of customs and transport infrastructure, active foreign economic contacts, and AO Karelsky Okatysh. The latter, situated in Kostomuksha, accounts for roughly one fifth of the Karelian economy, while a majority of rural municipalities remote from Petrozavodsk contribute no more that $1 \%$. At the same time, the population loss was smaller than the production decline, wherefore the share of unemployed has increased markedly in the periphery.

Reforms have induced economic renovation of Karelia, but little of it has happened in rural areas. The peripheral position and poor infrastructure of rural areas make their industrial revival unlikely. Regional authorities, struggling to save budgetary funds, shut down pieces of infrastructure, leaving the population deprived not only of social facilities, but even of energy supply. One possible solution is to engage renewable energy sources, particularly in agricultural cooperation arrangements. 


\section{ENTREPRENEURSHIP AND SUSTAINABILITY ISSUES}

ISSN 2345-0282 (online) http://jssidoi.org/jesi/

2020 Volume 7 Number 4 (June)

http://doi.org/10.9770/jesi.2020.7.4(51)

\section{Conclusions}

Green economy and renewable energy have lately been studied as a full-fledged research area both globally and in Russia. In particular, there is an ongoing search for engineering and process solutions for utilizing solar energy and promoting bioenergy; potential applications for green economy techniques are being investigated (Statista 2018). The task to promote alternative energy has been formulated within the UN Sustainable Development Concept, Renewable Energy Development Strategy 2020, a number of other international regulatory documents. All the countries leading in renewable energy utilization have for a long time been offering targeted support to the developments. The incentives for renewable energy development fall into three main groups: price-, cost-, and quantity-based. Price-based instruments include fixed prices per unit energy or price markup set in law, capacity charges (feed-in tariffs, net metering). These support measures were first introduced in the USA in the 1970's, but became widespread only in the 1990's. At the moment, price-based instruments are the most popular, applied in more than 50 countries. Cost-based instruments include various subsidies, tax abatements, partial reimbursement of investments in renewable energy developments. Quantity-based instruments include renewable energy quotas or green credits, as well as assistance in tendering. As a rule, quantity-based instruments are applied to more mature technologies for renewable energy use.

Furthermore, renewable sources of energy have a substantial environmental-economic potential and contribute to the country's innovative development. Finnish experience, for instance, proves that installations utilizing renewable energy can operate even in the north. To activate the use of renewable energy in Russia, foreign experience needs to be adapted and a systemic approach should be employed in implementing the energy saving and energy efficiency policies. The possible incentives for renewable energy development, given the existing potential and scientific developments, can take the form of support measures of all the three major types: price-, cost-, and quantity-based. However, since the threats for the energy security and, hence, the socio-economic security are higher in northern peripheral regions, they should be treated preferentially within the incentive mechanisms.

\section{References}

Adams S., Nsiah C. (2019). Reducing carbon dioxide emissions; Does renewable energy matter? Science of the Total Environment, 693, 133288. https://doi.org/10.1016/j.scitotenv.2019.07.094

Chang W-R, Hwang J-J, Wu W. (2017). Environmental impact and sustainability study on biofuels for transportation applications. Renewable and Sustainable Energy Reviews, 67, 277-288. https://doi.org/10.1016/j.rser.2016.09.020

Charfeddine L., Kahia M. (2019). Impact of renewable energy consumption and financial development on CO2 emissions and economic growth in the MENA region: A panel vector autoregressive (PVAR) analysis. Renewable Energy, 139, 198-213. https://doi.org/10.1016/j.renene.2019.01.010

Cherni A., Jouini S.E. (2017). An ARDL approach to the CO2 emissions, renewable energy and economic growth nexus: Tunisian evidence. International Journal of Hydrogen Energy, 42, 29056-29066. https://doi.org/10.1016/j.ijhydene.2017.08.072

Cho Y., Lee J., Kim T.-Y. (2007). The impact of ICT investment and energy price on industrial electricity demand: Dynamic growth model approach. Energy Policy, 35(9), 4730-4738. https://doi.org/10.1016/j.enpol.2007.03.030

Del P. Pablo-Romero M., Sánchez-Braza A., Expósito A. (2019). Industry level production functions and energy use in 12 EU countries. Journal of Cleaner Production, 212, 880-892. https://doi.org/10.1016/j.jclepro.2018.11.296

Dhar A., Naeth M., Jennings P., El-Din M. (2019). Perspectives on environmental impacts and a land reclamation strategy for solar and wind energy systems. Science of the Total Environment, 134602. https://doi.org/10.1016/j.scitotenv.2019.134602 


\section{ENTREPRENEURSHIP AND SUSTAINABILITY ISSUES}

ISSN 2345-0282 (online) http://jssidoi.org/jesi/

2020 Volume 7 Number 4 (June)

http://doi.org/10.9770/jesi.2020.7.4(51)

Ermolenko B., Ermolenko G., Fetisova Y., Proskuryakova L. (2017). Wind and solar PV technical potentials: Measurement methodology and assessments for Russia. Energy, 137, 1001-1012. https://doi.org/10.1016/j.energy.2017.02.050

Ermolenko G. (2015). Renewable Energy status, potential and opportunities in Russia, presented at the Second Session of the group of Experts on Renewable Energy, Geneva. Retrieved December 25, 2019 from https://docplayer.net/30952101-Renewable-energy-statuspotential-and-opportunities-in-russia.html

Hájek M., Zimmermannová J., Helman K., Rozenský L. (2019). Analysis of carbon tax efficiency in energy industries of selected EU countries. Energy Policy, 134, 110955. https://doi.org/10.1016/j.enpol.2019.110955

Hernández F., Hernández-Campos M. (2011). The Development of the Renewable Energy Technologies in Spain. Smart Grid and Renewable Energy, 2(2), 110-115. https://doi.org/10.4236/sgre.2011.22013

Inglesi-Lotz R., Dogan E. (2018). The role of renewable versus non-renewable energy to the level of CO2 emissions a panel analysis of sub- Saharan Africa's Big 10 electricity generators. Renewable Energy, 123, 36-43. https://doi.org/10.1016/j.renene.2018.02.041

International Renewable Energy Agency. (2018). Renewable energy statistics 2018. Retrieved December 25 , 2019 from http://www.irena.org/publications/2018/Jul/Renewable-Energy-Statistics-2018

Ito K. (2017) CO2 emissions, renewable and non-renewable energy consumption, and economic growth: Evidence from panel data for developing countries. International Economics, 151, 1-6. https://doi.org/10.1016/j.inteco.2017.02.001

Jäger-Waldau A. (2007). Photovoltaics and renewable energies in Europe. Renewable and Sustainable Energy Reviews, 11(7), $1414-1437$. https://doi.org/10.1016/j.rser.2005.11.001

Komerath N., Komerath P. (2011). Terrestrial Micro Renewable Energy Applications of Space Technology. Physics Procedia, 20, 255269. https://doi.org/10.1016/j.phpro.2011.08.024

Lanshina T., Laitner J., Potashnikov V., Barinova V. (2018). The slow expansion of renewable energy in Russia: Competitiveness and regulation issues. Energy Policy, 120, 600-609. https://doi.org/10.1016/j.enpol.2018.05.052

Li M., Xu J., Xie H., Wang Y. (2018). Transport biofuels technological paradigm based conversion approaches towards a bio-electric energy framework. Energy Conversion and Management, 172, 554-566. https://doi.org/10.1016/j.enconman.2018.07.049

Marques A., Fuinhas J. (2012). Is renewable energy effective in promoting growth?. Energy Policy, 46(1), 434-442. https://doi.org/10.1016/j.enpol.2012.04.006

Moe E. (2012). Vested interests, energy efficiency and renewables in Japan. Energy Policy, 40(1), $260-273$. https://doi.org/10.1016/i.enpol.2011.09.070

Olkkonen V., Syri S. (2016). Spatial and temporal variations of marginal electricity generation: the case of the Finnish, Nordic, and European energy systems up to 2030. Journal of Cleaner Production, 126, 515-525. https://doi.org/10.1016/j.jclepro.2016.03.112

Paz Espinosa M., Pizarro-Irizar C. (2018). Is renewable energy a cost-effective mitigation resource? An application to the Spanish electricity market. Renewable and Sustainable Energy Reviews, 94, 902-914. https://doi.org/10.1016/j.rser.2018.06.065

Pisacane V.L. (2014). Space Systems Engineering. In: Macdonald M., Badescu V. (eds) The International Handbook of Space Technology. (pp 143-163). Springer Praxis Books, Springer: Berlin, Heidelberg. https://doi.org/10.1007/978-3-642-41101-4_7

Proskuryakova L., Ermolenko G. (2019). The future of Russia's renewable energy sector: Trends, scenarios and policies. Renewable Energy, 143, 1670-1686. https://doi.org/10.1016/j.renene.2019.05.096

Renewable Energy Policy Network for the 21st Century. (2019). Renewables 2016 Global Status Report. Retrieved December 25, 2019 from https://www.ren21.net/wp-content/uploads/2019/05/REN21_GSR2016_FullReport_en_11.pdf

Sadorsky P. (2012). Information communication technology and electricity consumption in emerging economies. Energy Policy, 48, 130135. https://doi.org/10.1016/j.enpol.2012.04.064 


\section{ENTREPRENEURSHIP AND SUSTAINABILITY ISSUES}

ISSN 2345-0282 (online) http://jssidoi.org/jesi/

2020 Volume 7 Number 4 (June)

http://doi.org/10.9770/jesi.2020.7.4(51)

Saidi K., Toumi H., Zaidi S. (2017). Impact of information communication technology and economic growth on the electricity consumption: Empirical evidence from 67 countries. Journal of the Knowledge Economy, 8(3), 789-803. https://doi.org/10.1007/s13132$\underline{015-0276-1}$

Sarma U., Karnitis G., Zuters J., Karnitis E. (2019). District heating networks: enhancement of the efficiency. Insights into Regional Development, 1(3), 200-213. https://doi.org/10.9770/ird.2019.1.3(2)

Sharmina M. (2017). Low-carbon scenarios for Russia's energy system: A participative backcasting approach. Energy Policy, 104, 303315. https://doi.org/10.1016/j.enpol.2017.02.009

Shepovalova O. (2015). Energy Saving, Implementation of Solar Energy and Other Renewable Energy Sources for Energy Supply in Rural Areas of Russia. Energy Procedia, 74, 1551-1560. https://doi.org/10.1016/j.egypro.2015.07.718

Statista. (2018). Primary Energy Consumption in Russia between 2010 and 2017, by Fuel (In Million Metric Tons of Oil Equivalent). Retrieved December 25, 2019 from https://www.statista.com/statistics/265611/primary-energy-consumption-in-russia-by-fuel/

Sun X., Zhou X., Chen Z., Yang Y. (2019). Environmental efficiency of electric power industry, market segmentation and technological innovation: Empirical evidence from China. Science of the Total Environment, 135749. https://doi.org/10.1016/j.scitotenv.2019.135749

Velkin V. I. (2014). Research efficiency of complex systems with spread spectrum renewable energy for electric power supply decentralized objects in Russia. WIT Transactions on Ecology and the Environment, 190(1), 437-444. https://doi.org/10.2495/EQ140421

von Weizsäcker E.U., Lovins A.B., Lovins L.H. (2014). Factor Four: Doubling Wealth-Halving Resource Use: A New Report to the Club of Rome. In: von Weizsäcker E. (eds). SpringerBriefs on Pioneers in Science and Practice, vol 28. (pp 127-141). Springer: Cham. https://doi.org/10.1007/978-3-319-03662-5_11

Vylegzhanin V. (2015). General considerations of the analysis of the Kuzbass retrospective. Gornyi Mountain information and analytical Bulletin, 1, 152-163. Retrieved December 25, 2019 from http://www.giab-online.ru/files/Data/2015/01/23_152-163_Vylegzhanin.pdf (in Russ.)

Wang J., Hu M., Tukker A., Rodrigues J. (2019). The impact of regional convergence in energy-intensive industries on China's CO2 emissions and emission goals. Energy Economics, 80, 512-523. https://doi.org/10.1016/j.eneco.2019.01.024

Wiser R. (2007). Can deployment of renewable energy put downward pressure on natural gas prices?. Energy Policy, 35(1), 295-306. https://doi.org/10.1016/j.enpol.2005.11.021

World Energy Council. (2016). World Energy Resources 2016. Retrieved December 25, 2019 from https://www.worldenergy.org/assets/images/imported/2016/10/World-Energy-Resources-Full-report-2016.10.03.pdf

Yoo S-H. (2003). Does information technology contributed to economic growth in developing countries? A cross-country analysis. Applied Economics Letters, 11(10), 679-682. https://doi.org/10.1080/1350485032000138971

Zhang F., Wang C., Xie G., Kong W., Jin S., Hu J., Chen X. (2018). Projection of global wind and solar resources over land in the 21st century. Global Energy Interconnection, 1(4), 443-451. https://doi.org/10.14171/j.2096-5117.gei.2018.04.004

Zheng Hong-Hao, Wang Zheng-Xin (2019). Measurement and comparison of export sophistication of the new energy industry in 30 countries during 2000-2015, Renewable and Sustainable Energy Reviews, 108, 140-158. https://doi.org/10.1016/j.rser.2019.03.038

\section{Acknowledgements}

Supported by the RFBR, Russia, Project No. 20-310-70005 


\section{ENTREPRENEURSHIP AND SUSTAINABILITY ISSUES}

ISSN 2345-0282 (online) http://jssidoi.org/jesi/

2020 Volume 7 Number 4 (June)

http://doi.org/10.9770/jesi.2020.7.4(51)

Sergey TISHKOV is Secretary for Science in the Institute of Economics, Karelian Research Centre, Russian Academy of Science. Research interests: innovation development, spatial development, regional innovation system, environmental risks, energeefficiency of economy.

ORCID ID: orcid.org/0000-0002-6061-4165

Anton SHCHERBAK is the Researcher in Institute of Economics, Karelian Research Centre, Russian Academy of Science. Research interests: sustainable development, regional innovation system, environmental risks, energeefficiency of economy.

ORCID ID: orcid.org/ 0000-0002-2259-9953

Valentina KARGINOVA-GUBINOVA is the Researcher in Institute of Economics, Karelian Research Centre, Russian Academy of Science. Research interests: sustainable development, risk management, environmental risks, energeefficiency of economy.

ORCID ID: orcid.org/ 0000-0002-8630-3621

Aleksander VOLKOV is the Junior Researcher in Institute of Economics, Karelian Research Centre, Russian Academy of Science. Research interests: sustainable development, spatial development, regional economic system, human capital, environmental risks.

ORCID ID: orcid.org/0000-0003-0451-8483

Arsen TLEPPAYEV is the Associate Professor, Faculty of Economic Sciences, Kazakh-German University. Research interests: Energy consumption, internet usage, digitalization, economic growth, environmental risks.

ORCID ID: orcid.org/0000-0001-9754-3383

Antonina PAKHOMOVA is the Professor, Platov South-Russian State Polytechnic University. Research interests: energy potential, recycling, fish waste, biowaste, biogas, bioenergy.

ORCID ID: orcid.org/0000-0002-4261-3097

Copyright (C) 2020 by author(s) and VsI Entrepreneurship and Sustainability Center

This work is licensed under the Creative Commons Attribution International License (CC BY).

http://creativecommons.org/licenses/by/4.0/

c) (i) Open Access 